\title{
Lumen
}

Selected Proceedings from the Canadian Society for Eighteenth-Century Studies

\section{Nature, Gender, and Genre in Anne Finch's Poetry: 'A Nocturnal Reverie'}

\section{Katherine M. Quinsey}

Volume 26, 2007

Imitation et invention au siècle des Lumières

Imitation and Invention in the Eighteenth Century

URI : https://id.erudit.org/iderudit/1012061ar

DOI : https://doi.org/10.7202/1012061ar

Aller au sommaire du numéro

Éditeur(s)

Canadian Society for Eighteenth-Century Studies / Société canadienne d'étude du dix-huitième siècle

ISSN

1209-3696 (imprimé)

1927-8284 (numérique)

Découvrir la revue

Citer cet article

Quinsey, K. M. (2007). Nature, Gender, and Genre in Anne Finch's Poetry: 'A

Nocturnal Reverie'. Lumen, 26, 63-77. https://doi.org/10.7202/1012061ar

Copyright (c) Canadian Society for Eighteenth-Century Studies / Sociéte canadienne d'étude du dix-huitième siècle, 2007
Ce document est protégé par la loi sur le droit d'auteur. L'utilisation des services d'Érudit (y compris la reproduction) est assujettie à sa politique d'utilisation que vous pouvez consulter en ligne.

https://apropos.erudit.org/fr/usagers/politique-dutilisation/ 


\section{Nature, Gender, and Genre in Anne Finch's Poetry: 'A Nocturnal Reverie'}

In the late twentieth-century recovery of early women writers, Anne Finch, Countess of Winchelsea, was one of the earliest figures to be canonized; her modern restoration began in 1903 with Myra Reynolds's publication of Poems of Anne Finch, Countess of Winchelsea, and her prominence continued through full-length critical studies by McGovern and Hinnant in the 1990s. ${ }^{1}$ According to Carol Barash and Margaret Ezell, Finch is the one female poet of the period who has maintained a place in both the general Augustan canon and in the canon of 'women's literature. ${ }^{2}$ Finch is now a staple of undergraduate survey courses, particularly because of the precision and subtlety of her verse, and the accessibility of its subject matter. Her popularity goes back over two centuries, however, and crosses boundaries from classical to romantic, as pointed out by Reynolds in her introduction: Finch's verses were recited by mothers to their daughters, while the male Romantic poets imitated her tropes. Finch thus has a long history of transcending seemingly oppositional categories: gender boundaries, in that she appeals to both male and female readers, and philosophical and aesthetic boundaries between seventeenth-century and Romantic modes. As Barash states, Finch 'is arguably the best woman poet of the Augustan period, her work crucial in making links between the seventeenth-century royalist women's tradition ... a and the private, emotional landscapes

1 Myra Reynolds, ed., Poems of Anne Finch, Countess of Winchelsea (Chicago: University of Chicago Press, 1903); Barbara McGovern, Anne Finch and her Poetry: A Critical Biography (Athens and London: Georgia University Press, 1992); Charles H. Hinnant, The Poetry of Anne Finch: A Critical Interpretation (Newark and London: University of Delaware Press; Associated University Presses, 1994).

2 Carol Barash, English Women's Poetry 1649-1714: Politics, Community, and Linguistic Authority (Oxford: Clarendon Press, 1996), 259; she cites Margaret Ezell, Writing Women's Literary History (Baltimore: Johns Hopkins University Press, 1993), 127-29. 
idealized in nineteenth-century women's writing and also in Romantic ideals of lyric voice. ${ }^{3}$

'A Nocturnal Reverie,' which appeared as the concluding poem in Finch's first and only contemporary collection of published verse, was one of Finch's most popular poems from then until now, in part because it spans so smoothly the trajectory from the Cavalier to the Romantic tradition in English poetry. ${ }^{4}$ Indeed, Finch was claimed by William Wordsworth as a literary foremother, one of the few good writers to come out of the benighted age of classical convention; he singled out 'A Nocturnal Reverie' in an appendix to the Preface to the Lyrical Ballads as an example of a poem whose vivid sensory writing suggests 'the eye of the Poet had been steadily fixed upon [her] object' and that 'her feelings had urged [her] to work upon it in the spirit of genuine imagination. ${ }^{5}$ Recent criticism, however, has hastened to liberate Finch from the imputation of the Wordsworthian sublime. ${ }^{6}$ Most recently, Christopher Miller convincingly roots Finch in the seventeenth-century literary tradition of pastoral retirement poetry, and of its related mode, the nocturne - a rural poem in praise of night, reclaiming darkness and silence as a means of clarifying the soul from the delusions and distractions of the day.7 The rhetorical model for the nocturne is Milton's Il Penseroso; at the same time, as both Miller and earlier scholars point out, the mode also anticipates the poetry of the mid-eighteenth century where nocturnal wandering becomes the privileged setting for the work of the imagination: Edward Young's The Complaint or, Night Thoughts on Life, Death and Immortality (1742-45), William Collins's 'Ode to Evening' (1747), Thomas Gray's Elegy Written in a Country Church-

3 Barash, English Women's Poetry, 259. Reuben A. Brower points out Finch's affinities with seventeenth-century poetic tradition in 'Lady Winchilsea and the Poetic Tradition of the Seventeenth Century, 'Studies in Philology 42 (1945): 61-80.

4 Miscellany Poems, On Several Occasions, Written by a Lady (London, 1713). Barash points out that Finch was the first to publish a poetic miscellany as 'by a Lady,' though such an appellation had become relatively common in the mid-eighteenth century $(263,263 n)$; this fact indicates that Finch is on the cusp of a shift in women's image in the literary marketplace. See also Jean Mallinson, 'Anne Finch: A Woman Poet and the Tradition,' Gender at Work: Four Women Writers of the Eighteenth Century, ed. Ann Messenger (Detroit: Wayne State University Press, 1990), 50.

5 Qtd. in Reynolds, Poems of Anne Finch, lxxv, qtd. in Mallinson, 'A Woman Poet and the Tradition,' 62 . McGovern, Anne Finch and her Poetry, 78-83; Hinnant, The Poetry of Anne Finch, 27.

7 Christopher R. Miller, 'Staying Out Late: Anne Finch's Poetics of Evening,' Studies in English Literature 45, no. 3 (2005): 603-25. 
Yard (1751) - not to mention Wordsworth himself in his first published poem, An Evening's Walk (1793). ${ }^{8}$ More interesting in Miller's essay is his illustration of how Finch rewrites the gendered dualities in Milton's representation of night visions. On the one hand, in Eve's satanic dream in Paradise Lost, Book 5, Satan prepares her for temptation by drawing her off into a nocturnal ramble, without Adam and without need of sleep, where she is tempted with a vision of stars admiring her stellar beauty. As Miller says, this is a nocturne in its own right:

Why sleep'st thou Eve? now is the pleasant time,

The cool, the silent, save where silence yields

To the night-warbling Bird, that now awake

Tunes sweetest his love-labour'd song: now reigns

Full-orb'd the Moon, and with more pleasing light

Shadowy sets off the face of things; in vain,

If none regard; Heav' $n$ wakes with all his eyes,

Whom to behold but thee, Nature's desire,

In whose sight all things joy, with ravishment

Attracted by thy beauty still to gaze. (5. 33-47, qtd. in Miller, 612)

This is a nocturne that reiterates traditional gendered hierarchies, associating night with female vanity and delusion, and with femininity as the lesser term, inferior to rational day, as Eve is to Adam, playing on that model to foreshadow the temptation and fall ('[Thou] should'st be seen / A Goddess among Gods, ador'd and serv'd / By Angels numberless,' 9. 546-548). ${ }^{9}$ On the other hand, Milton's own night visions turn dream and night wandering into spiritual clarity and vision; blind during the day, at night the poet can visit 'a dream landscape' where 'the wakeful Bird / Sings darkling, and in shadiest Covert hid / Tunes her nocturnal Note' (3. 38-40, qtd. in Miller, 613). Miller argues that Finch wittily revisits these scenes from Milton, 'combining Miltonic inspiration with Lockean empiricism, to create an Eden without Satan, an Eve without Adam' in a 'gender-inflected' rewriting of pastoral and nocturne. ${ }^{10}$

I would argue, however, that in 'A Nocturnal Reverie' sensory immediacy, generic resonance, and 'gender inflect[ion]' go much deeper,

8 Ibid., 618.

9 Where not otherwise indicated, quotations from Milton are from Merritt Y. Hughes, ed., John Milton: Complete Poems and Major Prose (New York: Bobbs-Merrill, 1957).

10 Miller, 'Staying Out Late,' 605. 
creating in the poem a unique voice that transcends the trajectory from seventeenth-century to Romantic, and subtly epitomises ideas at the core of Finch's feminist concerns. The quality of immediacy in the 'Reverie' is unlike anything in Milton's Il Penseroso, Gray's Elegy, or Wordsworth's 'Lines Written a Few Miles above Tintern Abbey' (1798) - all of which are poems that use contemplation of landscape as a vehicle to something else. The first two, peopled by personified abstractions, are really about philosophical contemplation, not night or landscape as such, and even 'Tintern Abbey' is not about landscape per se, but about the poet's imagination. Finch's sensory immediacy, observed by all her major critics, and her 'distinctively personal tone' ${ }^{\prime 11}$ stand outside this tradition, as does her identification of subject with object, ${ }^{12}$ of poet with poetry, of seer with thing seen (or heard or smelt). In this poem, Finch recreates temporarily an Edenic state by dismantling the boundaries between human and non-human, soul and physical senses, poetic sensibility and sensory world. It is an Eden, moreover, that does away with the familiar rhetoric of dominion and naming associated with Adam, in favour of a shared community with the creation. The poem invokes a specifically gendered dynamic familiar to students of Enlightenment ways of knowing: it is structured around implied oppositions between violence and peace, imposed restraint and freedom, doing and being most vividly seen in the opposition between the 'sedate content' of the soul associated with night, where sensory experience leads to an experience beyond language and sense, and the 'fierce light' of day ruled by 'tyrant Man':

Their shortlived jubilee the creatures keep,

Which but endures, whilst tyrant Man does sleep;

When a sedate content the spirit feels,

And no fierce light disturbs, whilst it reveals;

But silent musings urge the mind to seek

Something, too high for syllables to speak; $(37-42)^{13}$

11 Katharine Rogers, 'Anne Finch, Countess of Winchelsea: An Augustan Woman Poet,' Shakespeare's Sisters: Feminist Essays on Women Poets, ed. Sandra M. Gilbert and Susan Gubar (Bloomington: Indiana University Press), 45; qtd. in Miller, 619n.

12 Jennifer Keith discusses this element in Finch's poetry in an illuminating argument; see 'The Poetics of Anne Finch,' Studies in English Literature 38, no. 3 (1998): 465,475 .

13 All quotations from 'A Nocturnal Reverie' and 'The Introduction' are taken from The Meridian Anthology of Early Women Writers: British Literary Women from Aphra Behn to Maria Edgeworth, ed. Katharine Rogers and William McCarthy (New York: 
Here Finch rewrites the traditional association of day with light, reason, knowledge, and order (not to mention Phoebus Apollo, whom she treats with scant reverence elsewhere in her work $)^{14}$ and links it specifically with the dominion of Man, or Adam, the knowledge that establishes dominion by naming things, fixing their meaning, and so controlling them: more broadly, the invasive knowledge founded on the Enlightenment subject-object dynamic that 'disturbs, whilst it reveals. ${ }^{\prime 15}$ This masculinist knowledge is in the poem ultimately trivialised into delusive 'pleasures' and the 'confusion' of the day, while experiential, feminine knowledge breaks down as far as possible those boundaries between observing self and other, as the soul 'joys in th' inferior world, and thinks it like her own' (46).

Edenic imagery of night and shade, opposed to daylight, is a strongly recurrent theme in Finch's work, often associated with her privatelyvoiced feminist concerns. As Finch herself points out, the loss of political and public prestige with the departure of James II, and her subsequent exile and retreat to the country, freed her from public social restraints on her writing, as described in her self-depreciatory preface to her 1713 collection: moving to 'the solitude, \& security of the Country' liberated her from fears of public opprobrium and provided her with food for her imagination in a sense that anticipates Wordsworth: 'But when I came to Eastwell, and cou'd fix my eyes only upon objects naturally inspiring soft and Poeticall immaginations ... I could no longer keep within the limmitts I had prescrib'd myself' (8, qtd. in Mallinson, 60). As has long been noted, the image of the Fall is resonant in Finch. It is used in 'The Petition for an Absolute Retreat' as the metaphor for the

New American Library, 1987), 105-06, 78-79. Unless otherwise indicated, all other quotations from Finch are taken from the Miscellany Poems of 1713, full-text version: http://lion.chadwyck.com.

14 In The Circuit of Apollo, Apollo is described as a somewhat ineffectual Restoration fop who must defer ultimately to female authority.

15 These are now well-established terms in studies of gender and early modern scientific discourse, with foundational studies by Carolyn Merchant and Evelyn Fox Keller; a more recent study focusing on ecology and gender is Sylvia Bowerbank's. See Merchant, The Death of Nature: Women, Ecology, and the Scientific Revolution (San Francisco: Harper \& Rowe, 1980); Keller, Reflections on Gender and Science (New Haven: Yale University Press, 1985); and Bowerbank, Speaking for Nature: Women and Ecologies of Early Modern England (Baltimore: Johns Hopkins University Press, 2004). The distinction itself is a rewriting of Milton's own duality between Adam's abstract reasoning and Eve's experiential, sensory knowledge, as depicted in Paradise Lost. Keith sees Finch as rejecting the objectifying mode in Augustan poetry, whereby the poet has authority by naming, in favour of an experiential model (475). 
fall from power of the Stuarts and the Finches themselves; there it is turned around to a paradise regained for Heneage and Anne - notably, a paradise in which Finch retells the Miltonic version of Genesis with herself as Adam, alone, fed by innocent fruits, then provided with a partner:

Give me there (since Heaven has shown

It was not Good to be alone)

A Partner suited to my Mind,

Solitary, pleas'd and kind,

When but Two the Earth possest,

'Twas their happiest Days, and best. (104-7, 112-13)

On the other hand, the loss of Eden is also accepted by Finch in the traditional Judaeo-Christian interpretation (transmitted through Milton as well), which held Eve responsible for the Fall, ${ }^{16}$ yet she also subtly questions that model, problematizes it, and even pushes it over the edge into irony, as seen in 'A Poem, Occasion'd by the Sight of the $4^{\text {th }}$ Epistle Lib. Epist: 1. Of Horace':

Happy You three! happy the Race of Men!

Born to inform or to correct the Pen

To Proffitts pleasures freedom and command

Whilst we beside you but as Cyphers stand

T'increase your Numbers and to swell th'account

Of your delights which from our charmes amount

And sadly are by this distinction taught

That since the Fall (by our seducement wrought)

Ours is the greater losse as ours the greater fault

(63-73, qtd. in Mallinson, 69)

This poem would not seem to be entirely innocent of the kind of sarcasm that informs Mary Astell's bitter rebuke to male authority in Some Reflections on Marriage. Indeed, it encapsulates even more precisely than

16 Mallinson, 'A Woman Poet and the Tradition,' 69. It is worth noting the context of feminist controversy during the time of Finch's manuscript poetry; Halifax's Advice to a Daughter, reiterating standard tropes of female inferiority and absolute submission in marriage, went into seven editions in eleven years following 1688 and the fall of James II, coinciding with feminist essays by Mary Astell and Mary Chudleigh among others, and a feminist focus in plays by Southerne and Vanbrugh. 
Astell the issues at the heart of feminist critique of patriarchal structures - the complaint that women are ciphers, empty of substance and identity, vessels existing solely for breeding and men's entertainment.

Finch rewrites the Fall in another sense, making overt the potentially feminist complaint behind her apparent acquiescence, in a poem unpublished during her lifetime but now more anthologized than any other - 'The Introduction' - the introduction to her unpublished folio volume. ${ }^{17}$ Here the Fall is a metaphor for the loss of power and integrity occasioned by false education, trivialising pursuits, and the social construction of women as objects for domestic 'Use' (20). Following the ascending scale of Biblical examples of feminine power culminating in Deborah, ruler and judge of Israel ("Then, to the peaceful shady palm withdraws, / And rules the rescued nation with her laws,' 49-50), Finch shifts abruptly to the paradise lost of her present day, where the true laws of Deborah are succeeded by the 'mistaken rules' of paternalistic convention, in language that epitomises the concept of construction of gender ('expected and designed') while it coincides with Astell's comparable critique of the double bind of women's vitiated education:

How are we fallen, fallen by mistaken rules?

And Education's more than Nature's fools,

Debarred from all improvements of the mind

And to be dull, expected and designed. (51-54)

The 'peaceful shade' of woman-ruled Israel elides into the shade of country retirement, shades associated elsewhere with the Edenic harmony of Finch's marriage and the unfallen rules of poetry. Shades and windings are conventional tropes of pastoral poetry, not only associated with idealised sylvan retirement but also linked with overtones of the nocturne; the pastoral retirement of 'shade' is given a subtly feminist twist in Finch, a double edge, as we have seen when she makes exile a place of freedom from gender-based social restraint. 'Shade' in this period is primarily a synecdoche for trees, and is only secondarily associated with twilight; the blurring of distinction that Ruth Salvaggio speaks of in describing Finch's counter-discourse to the Enlightenment 'discourse of light' is apparent, as the sensory and emotive effect of the two is similar. ${ }^{18}$ Pastoral convention inverts the negative associations

17 McGovern, Anne Finch and her Poetry, 69.

18 Ruth Salvaggio, Enlightened Absence: Neoclassical Configurations of the Feminine (Urbana: University of Illinois Press, 1988), 105-26, qtd. in Miller, 604, 619n. The phrase 
of shade and windings with confusion, wandering, darkness, and delusion (a duality seen in Milton and Spenser, both masters of the pastoral, where mazy hair, winding serpents, bowers of bliss, and woods of error, emblems of deception, exist in ironic opposition to their valorised counterparts, wedded bowers and leafy luxuriance). The tropes are used repeatedly in Finch with a comparable double edge, redefined in personal terms; in 'The Petition,' she suggests the dualities of the shades and windings, in language that suggests the idea of wandering ('lost') as linked not with error but with 'Liberty':

Give me yet, before I Dye,

A sweet, but absolute Retreat,

'Mongst Paths so lost, and Trees so high,

That the World may ne'er invade,

Through such Windings and such Shade,

My unshaken Liberty. (2-7)

The concept of hortus conclusus, a traditional icon of the feminine from the male perspective, is appropriated by Finch to express the feminine point of view, as it is associated specifically with freedom from social domination as well as with silence, both the silence of peace and the loss of a public voice. ${ }^{19}$ 'Unshaken Liberty' is an interesting expression here, evocative of Whig politics and the Lockean models that fed into feminism such as Astell's. This poem thus complicates the apparent bitterness at the end of 'The Introduction' ('For groves of laurel thou wert never meant; / Be dark enough thy shades, and be thou there content' [63-64]), as 'Shades' are associated both with restraint or exile, and with freedom (intellectual, social, and physical). Moreover, 'The Petition' goes on to elide the sylvan shades specifically with those of night:

Be no Tidings [of court gossip] thither brought,

But silent, as a Midnight Thought,

Where the World may ne'er invade,

Be those Windings, and that Shade. (18-21)

'Discourse of Light' refers to David C. Lindberg and Geoffrey Cantor, The Discourse of Light from the Middle Ages to the Enlightenment (Los Angeles: Clark Memorial Library, 1985) (Miller, 619n).

19 See Mallinson, 'A Woman Poet and the Tradition,' 65. 
'A Nocturnal Reverie' thus draws on themes already strongly 'genderinflected' in Finch. While it invokes Milton's contrast of delusive day with night's contemplative truth, it does so in terms that specifically recall female experience and longstanding gendered oppositions. In keeping with the Miltonic nocturne, the poem reverses the conventional binary associating day with Phoebus, knowledge, reason, clear judgment, and order, and night with darkness, error, confusion, loss of distinction, and delusive fancy. Unlike Milton, however, the 'Reverie' does not reclaim Night as the time of clarity of mental and spiritual perception owing to the fading of physical perception (specifically, eyesight), but it claims superior sensory acuity as well, in an experience combining all the senses, and links that sensory experience directly to the spiritual. In this it is more Wordsworthian: the sensory experience of Nature opens up intuitive knowledge and heightens spiritual awareness. ${ }^{20}$ Finch describes this process in specifically gendered terms, contrasting the multisensory knowledge of the night, which becomes a means to supersensory knowledge, to the 'fierce light' of day, Phoebic knowledge that 'disturbs, whilst it reveals' and which is ruled by 'tyrant Man.' Additionally, Finch varies from the seventeenth-century nocturne in her use of poetic point of view; as the perceiving poetic subject is identified with the object perceived, the subject-object distinction is blurred, and the perceiver enters into a community with things perceived. She describes this process specifically in Edenic terms, at the same time drawing on traditional gender distinctions linking woman with the natural world; the female perceivers / walkers are associated with the natural creation, especially with the animals, in an Edenic return to harmony but without 'dominion' (an ideal, incidentally, also expressed by Pope - 'Man walk'd with beast, joint tenant of the shade' [Essay on Man 3.152]). ${ }^{21}$

The poem is structured substantively rather than lineally, piling up adverbial and adjectival phrases and clauses describing 'such a night,' gradually unfolding sensory experience, to culminate in a suggestion of experience beyond the senses and beyond language, in a union of soul and body, seer and thing seen (the soul 'joys in th' inferior world, and thinks it like her own'). Only then does the poem reach its main

20 Finch's use of synaesthesia challenges the Lockean emphasis on vision as the primary faculty at this time, which remained central to concepts of imagination through the Romantics. Note that Wordsworth, too, privileges eyesight, describing visual landscapes; for sounds, smells, the nocturnal mode, we need to look to Keats.

21 Butt, John, ed. The Poems of Alexander Pope (New Haven: Yale University Press, 1976), 530. All quotations from Pope are taken from this edition. 
clause, with a return to the beginning - 'In such a night let me abroad remain.' As Miller points out, it calls itself a 'reverie,' that is, 'a form of cognition,' not a poetic kind. There is a possible allusion to Katherine Philips's 'The Resverie,' published in her posthumous collection of 1667, another poem in praise of virtuous retirement; the dream mode was in vogue at this time, associated with the dream state, discussed by Locke as distinct from deliberate acts like meditation or contemplation. ${ }^{22}$ Finch diverges from this tradition, however, in that 'A Nocturnal Reverie' is not dreamlike in form but physically vivid; the soul's ecstasy is more like active meditation, arising from sensory enjoyment. The poem does not negate vision: one can see a good deal - even blades of grass, now refreshed and erect, relieved from the heat of the day, in a revisitation of both Milton's and Donne's sensuous grassy banks: 'The freshened grass now bears itself upright, / And makes cool banks to pleasing rest invite' (11-12). The idea of veiled or illusory vision is given positive value: 'passing clouds' that 'thinly veil the heavens' mysterious face' in a rewriting of the satanic nocturne make heaven's face now the object of awe, not a means of female vanity; and the pastoral convention of trees reflected in the water, 'waving moon and trembling leaves,' is not an illusion but imaginative recreation, suggesting life in all things. Shadows and concealment, normally seen as delusive, are now transformative: ruins are more venerable, harvest fertility swells into active verbal abundance. The synaesthesia, or linking of sight with hearing and smell, also provides a means by which the perceiver and the object perceived are identified with one another, as 'odors,' like the poet, 'through temperate air uninterrupted stray,' with the same linking of wandering not with error but with freedom from the 'interruption' associated with 'repelling day.'

Finch incorporates elements of the traditional negative associations of night with delusion, with the glow-worms (emblems of ephemerality, false-light, and vanity), but transfers the sting to social satire, blurring the glow-worms' 'trivial beauties' with the ephemeral beauty of society belles (a common theme at the time, epitomised in Pope's Belinda), and thus with the dullness and triviality seen by Finch and

22 Miller, 'Staying Out Late,' 614. Philips, of course, specialized in the virtuous retirement theme characteristic of Cavalier poetry, and in 'A Country Life' she praises rural retirement as Edenic in terms anticipatory of Behn's The Golden Age. But Philips's Resverie is actually an entirely conventional paean to the retired vir bonus, an extended praise of the virtuous man, with little suggestion of an actual dream fantasy or of feminine concerns. Possibly the reverie as a form is feminist irony, suggesting the dreamlike nature of a wished Edenic world to be had briefly. 
Astell as being imposed upon women by vitiated education and patriarchal social norms. This link is made explicit by the contrast to her friend (and companion on the walk?) the Countess of Salisbury (probably Anne Tufton, the daughter of one of Finch's close friends), ${ }^{23}$ with both moral and physical beauty that create their own light: Philips's vir bonus in retirement is now applied to women. The mention of Salisbury further suggests the possibility of a non-solitary night walk, one with a congenial Edenic 'partner,' only this one is female.

The relationship between the female walkers / perceivers and the natural, particularly the animal, world dominates the second part of the poem. This natural relationship is structurally linked with the higher state of the soul, as that climactic passage is framed with, and introduced by, accounts of the women's closeness to the animals, in what could be read as a potentially ecofeminist challenge to traditional hierarchies of being. The other element linking women with the animal creation is that of freedom during the night from their daytime subjection to 'tyrant Man,' and from violent domination or 'rage.'

From the very opening line, the poem suggests the idea of potential violence contained ('rage disarm'd'; louder winds caged and far away). While this element is sometimes read as proto-Gothic terror or imagination, it is in fact more political than emotive, as the potential for violence and its being 'disarm' $\mathrm{d}$ ' during the night are associated with the daytime domination of 'tyrant Man' over both women and animals. The famous example of the horse, sometimes read as Gothic, and read by Miller as pastoral (615), is on another level a vivid, literal rendition of the experience of women walking unescorted in a wood at night, and also of what horses sound like in the dark:

When the loosed horse now, as his pasture leads,

Comes slowly grazing through th' adjoining meads,

Whose stealing pace and lengthened shade we fear,

Till torn up forage in his teeth we hear (29-32)

The sound of a horse eating at night is a homely, comforting sound; these are not teeth to be feared. The potential threat feared seems more like a human threat such as a poacher or thief or stalker, potential human male violence, defused by the revelation that it is a fellow creature who, like the women, is 'loosed' during the night to wander free. This encounter introduces the catalogue of vividly depicted farm 
animals, all portrayed as free from the diurnal domination of 'tyrant Man': sheep are 'at large,' cattle are 'unmolested' (curious choice of participle here), the maternal partridge calls to her brood unpursued by hunters (potential violence is disarmed, in favour of a strongly female image). The catalogue concludes with an appositional statement or aside: 'Their shortlived jubilee the creatures keep, / Which but endures, whilst tyrant Man does sleep' (37-38). The 'jubilee' refers to the Old Testament law of the 'jubilee year' given to Israel by God through Moses; every fiftieth year, for one full year, slaves were to be freed and fields left unploughed to ensure physical, social, and spiritual renewal. This cryptic Biblical reference has common ground with resonant images from the feminist discourse of Finch's time. Slavery and marriage were directly equated by Astell in Some Reflections on Marriage, as she quotes Locke's definition of slavery in the same passage in which she refers to men as 'tyrants': 'If all men are born free, how is it that all women are born slaves? As they must be, if the being subjected to the inconstant, uncertain, unknown, arbitrary will of men, be the perfect condition of slavery?'24 The fields freed from ploughing echo the imagery of the third stanza of Behn's The Golden Age, celebrating the time when Edenic earth was not subjected to the 'rude rapes' of the 'stubborn plough.' The plough in Behn's poem is not only an image of the inherent violence of human civilisation begun with agriculture and ending in wars and tyrannies, but also, more directly, a reference to the curse on Adam and Eve in Genesis, whereby the earth no longer gave willingly to man, but now must be forced; the analogue, in human sexual relations, was that the woman's curse was to be subject to her husband (to male domination and control) and to bring forth children with pain. In both cases, humans and the earth, man and woman, the original harmony is lost, to be replaced by a relationship of power, domination, and violence.

This packed aside introduces the climactic passage on the soul's ultimate freedom, foretasted at night, the final 'when' which moves away from sensory description to the state of the soul:

When a sedate content the spirit feels,

And no fierce light disturbs, whilst it reveals;

But silent musings urge the mind to seek

Something, too high for syllables to speak; (39-42) 
The substantive 'sedate content' arises from experiential, non-hierarchical, and intuitive understanding that acknowledges its own limits beyond language and beyond human reasoning, in the realm of highest intuitive perception (Milton's angelic reason) achieved through sensory imagination (Wordsworth), and so to the line that spans or transcends conventional literary tradition, as '[Miltonic] silent musings urge the mind to seek / [a Wordsworthian] Something, too high for syllables to speak.' But this higher knowledge can only be achieved in the absence of the 'fierce light [that] disturbs, whilst it reveals': Finch provides one of the most economic descriptions in the canon of the invasive rationalistic knowledge of the Enlightenment (Milton's discursive reasoning which brought about the Fall) that pretends to know all things, to name them, as Adam did, in an act of dominion, and so to define and control them. This is the Phoebic knowledge associated with day, with distinction and conventional naming, and with the order of masculine power.

This diurnal knowledge is negated and set aside by the passage's syntax, as a reminder of 'rage disarm'd.' Here the higher knowledge of the soul becomes a process, as striving to experience 'something, too high for syllables to speak' turns into an accomplishment of that state in which

The free soul to a composedness charmed,

Finding all the elements of rage disarmed,

$\mathrm{O}^{\prime}$ er all below a solemn quiet grown,

Joys in th'inferior world, and thinks it like her own. (43-46)

In this brief vision of a millenarian world where warring elements are at peace, the final line is ambiguous. McGovern and Brower take the passage to refer to the traditional Christian idea that the soul's true home is elsewhere; Miller sees the poet, or her soul, as taking the moon's perspective, looking down on the creation. ${ }^{25}$ The Edenic world of Night has made the earth a paradise, similar to the heaven that is the soul's home, and the soul 'joys in that world' - the state of ecstasy itself is an extension of the act of sensuous perception and enjoyment. But the 'her,' while referring syntactically to 'the free soul,' can also refer to the female perceiver, herself at this time a 'free soul,' and the 'inferior world' to that of the animals and the natural creation, that is like her own in more ways than one. 
The actual main clause of the poem follows this climactic affirmation, with a return to the poem's present; it is unclear whether this powerful depiction of spiritual freedom is in the indicative or subjunctive, has happened, or should / would happen. The refrain 'in such a night,' repeated three times, is similarly ambiguous in mood: an actual night? or night that should be? a night like this one? As Miller astutely points out, this is not a prayer; there is no authority in this poem - no goddess Melancholy or divine or masculine presence to whom she is praying. ${ }^{26}$ 'Let me abroad remain' is not a request for permission but a fiat, a declaration of power, calling into being; the freedom to wander 'abroad,' the ability to 'remain' in that freedom, are invoked in words of authority.

As is characteristic of Finch, the declaration of power and freedom is sharply drawn back with a recognition of limitations, with an anticlimactic pulling back in the last line: ${ }^{27}$

In such a night let me abroad remain,

Till morning breaks, and all's confused again;

Our cares, our toils, our clamors are renewed,

Or pleasures, seldom reached, again pursued. (47-50)

In an inversion of the traditional gendered binary of day and night, male and female, clarity and delusion, reason and imagination, the dawn is now associated with confusion, not with clarity. The 'toils' (a term suggesting postlapsarian Adam's world) are linked with the delusive pursuit of trivial pleasures, usually imputed to women (see Pope's Epistle to a Lady, 'Pleasures the Sex, as children birds, pursue' [231]). The final word echoes and contrasts with the pastoral image of sheep 'pursu[ing] their food' (33) peacefully, associated earlier in the poem with the higher pleasures sought by the soul; these are substantive, natural needs, as opposed to the ephemeral pleasures of the daytime round. These lines are the image of interruption (focussed in 'clamor,' the aural form of chaos, a continued state of interruption); in the light that disturbs and reveals, the imperfections of the fallen world are restored, and for women the Fall is reiterated by 'mistaken rules' into a

26 Miller, 'Staying Out Late,' 611.

27 This habit in Finch's poetry is a good example of what Marilyn Williamson calls 'undoing' in early modern women writers: the tendency to back away from directly confrontational statements, or to depreciate the worth of the work or the writer. See Williamson, Raising Their Voices: British Women Writers, 1650-1750 (Detroit: Wayne State University Press, 1990). 
daytime life of 'Good breeding, fashion, dancing, dressing, play' ('The Introduction,' 14).

'A Nocturnal Reverie' was in part responsible for Finch's misleading reputation as a 'nature poet' when she was first restored to the 'Publick View' in 1903 by Myra Reynolds's edition of some of her poetic manuscripts. ${ }^{28}$ In fact it is a poem that encompasses and transcends generic conventions, while at the same time it makes a notable claim for the relationship between gender and the natural world, in what could be called an example of early modern ecofeminism. The 'Reverie' is one of Finch's most subtle, yet most vivid, statements of feminist principle, of claims for the life of the mind and spirit for women, set in the context of constraint and objectification that deny that life; it is also a remarkably original poetic form and vision. As such, 'A Nocturnal Reverie' both epitomises and influences the changing trajectory of literary history.

\section{KATHERINE M. QUINSEY}

University of Windsor 